\title{
Effects of Lactic Acid Fermentation on the Retention of Beta-Carotene Content in Orange Fleshed Sweet Potatoes
}

\author{
Benard O. Oloo ${ }^{\mathrm{a}}$, Shitandi A. ${ }^{\text {b* }}$, Mahungu S. ${ }^{\mathrm{a}}$, Malinga J. B. ${ }^{\mathrm{c}}$, And Ogata B. \\ RosE $^{b}$ \\ a Department of Food Science and Technology, Egerton University, P.O Box 536, Egerton, Kenya \\ b Division of Research, Kisii University, P.O Box 408-40200, Kisii, Kenya \\ ${ }^{\mathrm{c}}$ Kenya Agricultural Research Institute, P.O Box 57811, Nairobi, 00200, Kenya \\ ${ }^{*}$ Corresponding author \\ ashitandi@kisiiuniversity.ac.ke \\ TEL: +254 (0)202352059 \\ FAX: +254 (0)202491131
}

Received: 14 March 2013; Published online: 18 April 2014

\begin{abstract}
This study aimed to establish the effects of lactic fermentation on the levels of $\beta$-carotene in selected orange fleshed sweet potato (OFSP) varieties from Kenya. Furthermore,it sought to demonstrate fermentation as a potential process for making new products from sweet potato with enhanced nutraceutical attributes. The varieties (Zapallo, Nyathiodiewo and SPK004/06) were fermented with Lactobacillus plantarum MTCC 1407 at $25 \pm 2^{\circ} \mathrm{C}$ for $48 \mathrm{~h}$ and kept for 28 days to make lacto-pickles. During fermentation both analytical ( $\mathrm{pH}$, titratable acidity (TA), lactic acid (LA), starch, total sugar, reducing sugar $\left(\mathrm{g} / \mathrm{kg}\right.$ roots), texture $\left(\mathrm{N} / \mathrm{m}^{2}\right), \beta$-carotene $(\mathrm{mg} / \mathrm{kg}$ roots $)$ ) and sensory (texture, taste, flavour and after taste) attributes of sweet potato lacto-juice were evaluated. Process conditions were optimized by varying brine levels, with fermentation time. A UV-visible spectrophotometer was used to identify and quantify $\beta$-carotene. Any significant variations $(\mathrm{p}<0.05)$ in analytical attributes between the fermented and unfermented samples ( $\mathrm{pH}, \mathrm{LA}, \mathrm{TA}$ and $\beta$-carotene concentration) of lacto-pickles, prepared from the potato roots, were assessed. The study reported a final composition of $156.49 \mathrm{mg} / \mathrm{kg}$, $0.53 \mathrm{mg} / \mathrm{kg}, 0.3 \mathrm{~N} / \mathrm{m}^{2}, 1.3 \mathrm{~g} / \mathrm{kg}, 5.86 \mathrm{~g} / \mathrm{kg}, 0.5 \mathrm{~g} / \mathrm{kg}$ and $5.86 \mathrm{~g} / \mathrm{kg}$ for $\beta$-carotene, Ascorbic acid, texture; Starch, total sugars, LA and TA respectively, and a pH of 3.27. The fermented products were subjected to flavour profiling by a panel. The product sensory scores were 1.5 to 2.5 on a 5 point hedonic scale, ranging from dislike slightly to like much. The products with brine levels at 4 and $6 \%$ were most preferred. The retention of $\beta$-carotene was $93.97 \%$. This demonstrated lactic acid fermentation as a better method for processing OFSP as the main nutritional attributes are retained. The final product was resistant to spoilage microorganisms after 28 days of fermentation. Further preservation could be obtained by addition of sodium metabisulphite. In conclusion, Lactic acid fermentation using $L$. plantarum is a novel method of producing Lacto pickles from Zapallo OFSP, with $93.97 \% \beta$-carotene retention and adequate shelf life.
\end{abstract}

Keywords: Ipomoea batatas; Lactobacillus plantarum; $\beta$-carotene; Lacto pickles; Kenya

\section{Introduction}

Sweet potato is an important staple food in tropical regions where it is grown up to an elevation of 2,000m above sea level (CIP, 2010). It ranks seventh of the most important food crops in the world according to FAOSTAT (2005) and is often considered a small scale farmer's crop (FAO- 
STAT, 2011). It is grown in abundance around major lakes in the East African Rift Valley of Uganda, Rwanda, Burundi, Tanzania and Kenya (Kapinga et al., 2005). Sweet potato roots are rich in starch, sugar, vitamin $\mathrm{C}, \beta$-carotene, iron and other minerals (Ray \& Ward, 2006). Their leaves are high in essential amino acids, lysine and tryptophan. These two amino acids are always limited in cereals thus, the sweet potato's leaves can easily complement cereal based diets in the region (Mwanri, Kogi-Makau, \& Laswai, 2011).

Some varieties of sweet potatoes contain coloured pigments such as $\beta$-carotene, anthocyanin and phenolic compounds. These pigments form the basis for classifying the foods as nutraceuticals (Ray \& Ward, 2006). Nutritionally, sweet potatoes usually have higher protein content than other tubers such as cassava and yams.

In Africa, sweet potatoes have been consumed without special processing for a long time. However, some communities in Busia, Kenya and Northern Uganda make flour from fermented sweet potato for ugali as a substitute during the dry season when they are faced with scarcity. Currently there is flour production in Kenya at Azurri Industries (Azuri Health Products, 2011). The fresh tubers are either boiled, baked, roasted or fried. Sweet potato flour and starch may also be processed. With the introduction of microwaves, such a method of Orange Fleshed Sweet Potato (OFSP) preparation is on the rise. Sweet potato varieties with dark orange flesh are richer in $\beta$-carotene than light fleshed varieties. Their increased cultivation is being encouraged in Africa where Vitamin A deficiency is a serious public health problem (van Jaarsveld et al., 2005). Utilizing new cultivars of OFSP that have nutritional benefits, and also contain pigments such as flavones, phenolic acids and anthocyanins, is one way to expand the market opportunities for the sweet potato industry (Suda, Oki, Masuda, Kobayashi, \& Furuta, 2003).

Bengtsson, Narnutebi, Alminger, and Svanberga (2008) compared the retention of all trans- $\beta$ carotene for steaming, drying and deep frying processes but not for lactic acid fermentation. They reported process losses of up to $25 \%$ on $\beta$-carotene. In a different study, van Jaarsveld, Marais, Harmse, Nestel, and Rodriguez-Amaya
(2006) reported losses of close to 20\%. (Panda, Parmanick, \& Ray, 2007) observed about 22.2\% losses in a selected Indian OFSP after blanching for $15 \mathrm{mins}$ at $100^{\circ} \mathrm{C}$. However, they reported a less than significant change in $\beta$-carotene in the varieties processed by fermentation. With regards to Kenyan varieties, there were no reports on the retention of $\beta$-carotene from OFSP varieties processed by lactic acid fermentation. Lacto-products produced by lactic acid fermentation are known to have nutraceutical attributes. They offer range potential in the beverage sector because of their high nutritive value. They act as substitutes for lactose intolerant individuals. Due to minimal or no heat treatment, they are likely to retain most of the heat labile vitamins, including $\beta$-carotene. The aim of the present study was to evaluate the retention of $\beta$-carotene from Kenyan OFSP varieties. The OFSP were processed by Lactic acid fermentation using Lactobacilus plantarum MTCC1407 starter culture for 28 days. The consumer acceptability of the processed OFSP was also evaluated based on the sensory attributes of flavor, appearance and after taste.

\section{Materials and Methods}

\subsection{Study site and Sampling procedure}

The study was carried out at Egerton University and the Kenya Industrial Research Development Institute (KIRDI) (South B, Nairobi) laboratories. The Kenya Agricultural Research Institute (KARI), Njoro is situated along the Njoro -Mau Narok road in Nakuru County. The site is elevated at an altitude of $2185 \mathrm{~m}$ above sea level and it lies between $0^{\mathrm{O}} 20^{\prime}$ South and $35^{\mathrm{O}} 56^{\prime}$ East of Kenya. The area receives an average rainfall of $939 \mathrm{~mm}$ per annum, and has a mean temperature of $14.9^{\mathrm{O}} \mathrm{C}$ (Jaetzold \& Schmidt, 2007). Sweet potatoes of the varieties: SPK/004/6, Zapallo and Nyawo (locally referred to as $\mathrm{Ny}$ athiodiewo) were collected from KARI, Njoro and used for the experiment. The OFSP samples were collected after 5-7 months' growth, during the peak harvesting season. The experiment was laid out in a Completely Randomized Block De- 
sign (RCBD). A ten day period was allowed to elapse before the second collection of replicate samples according to the procedure described by Panda et al. (2007). Samples were packed in 10-kg color-coded mesh bags and transported to KARI laboratories. The sweet potatoes were then kept at ambient conditions in a lockable compartment for use within 24 hours.

\subsection{General description of raw material samples used}

The samples were prepared by washing and cleaning with a soft brush under running tap water. Weights, colour and size of the cleaned samples were observed and recorded for the sweet potatoes. A top loading balance was used for weights. Colour was determined by comparison against the sweet potato RHS colour chart prepared by CIP (Burgos et al., 2009).

\subsection{Proximate analysis of fresh roots}

Proximate analysis of OFSP roots was performed using standard methods as detailed in the following sections.

\subsection{Moisture content determination}

Moisture content was determined by heating the sweet potatoes to a constant weight at $105^{\circ} \mathrm{C}$ for 3-6 hours and measuring the weight lost due to evaporation of water. The AOAC oven drying method 14.0004 was used (AOAC, 2000). The dry matter was calculated as the difference of moisture content from 100 .

\subsection{Crude protein determination}

The crude protein content was determined by the micro Kjeldhal method and 6.25 used as the conversion factor.

\subsection{Total ash determination}

Total Ash was determined by the muffle furnace method according to AOAC (2000).

\subsection{Crude fat determination}

The crude fat content was determined by Soxhlet extraction, using the standard method of the AOAC (2000).

\subsection{Crude fiber/Dietary Fibre}

The crude fibre of the fresh OFSP was determined according to the AOAC (1984) procedure 7.067, as modified by Gul and Safdar (2000).

$\%$ Crude fibre $=$ (weight of sample after oven drying - weight of sample after ashing) / original weight.

\subsection{Iron $(\mathrm{Fe})$ and Zinc (Zn) Analysis}

Iron and Zinc were determined by AtomicAbsorption Spectrophotometer (Model No. 3400, Perkin-Elmer, CA, USA) according to the procedure described in AOAC (2003).

\subsection{Analysis of $\beta$-carotene content}

0.2 grams OFSP for Zapallo to 6 gram for $\mathrm{Ny}$ athiodiewo was ground in a mortar and pestle, with some acid-washed sand, and then extracted completely with acetone. The different weights used was based on observed differences in the colour intensities between the two varieties. The volume of the combined extracts was raised to $50 \mathrm{ml}$ by adding acetone, and then dewatered with Anhydrous Sodium Sulphate. Twenty-five milliliters of this extract was evaporated to near dryness in a rotary vacuum evaporator. The separation was carried out in a chromatographic column packed with silica gel. The evaporated sample was dissolved in $2 \mathrm{mls}$ of petroleum spirit $\left(40^{\circ}-60^{\circ} \mathrm{C}\right)$, then quantitatively spotted into the column, and eluted with 
petroleum spirit. The first yellow eluate was collected in a $25 \mathrm{ml}$ flask and made to the mark with the petroleum spirit, according to a procedure by Muchoki, Imungi, and Lamuka (2007). The optical densities of the $\beta$-carotene fraction was measured at 450nm using a CE $440 \mathrm{UV} / \mathrm{Vis}$ Double Beam Scanning Spectrophotometer, that had been calibrated with standard solutions of pure $\beta$-carotene in petroleum spirit. The results were calculated as $\beta$-carotene equivalents (Imungi \& Wabule, 1990).

\subsection{Analysis of Ascorbic acid}

Ascorbic acid was determined by titration with 2, 6-Dichlorophenol-Indophenol dye (AOAC, 1984). 2 grams of sample was macerated using a mortar and pestle with $25 \mathrm{mls}$ of $20 \%$ metaphosphoric acid and the volume made to $100 \mathrm{ml}$ with distilled water. $10 \mathrm{ml}$ of this matrix was pipetted into a flask, followed with addition of 2.5 $\mathrm{ml}$ of acetone, and titrated to a faint pink end point. Standard indophenol solution was prepared by dissolving $0.05 \mathrm{~g}$ of 2, 6-dichlorophenolindophenol in distilled water, diluted to $100 \mathrm{ml}$ and filtered. Ascorbic acid standard solution was prepared by dissolving $0.05 \mathrm{~g}$ of pure ascorbic acid in a small volume of $5 \%$ Oxalic acid solution, and then diluted to $250 \mathrm{ml}$ with the same oxalic acid solution. $10 \mathrm{ml}$ of the ascorbic acid standard solution was titrated with the indophenol solution to a slight pink end point. The amount of ascorbic acid corresponding to $1 \mathrm{ml}$ of indophenol solution was then calculated. The standard indophenol solution was used to titrate $10 \mathrm{ml}$ of the filtrate. The vitamin $\mathrm{C}$ content was calculated as $\mathrm{mg} / 100 \mathrm{~g}$ sample. The slight modifications to AOAC (1984) were according to Ranganna (2001).

\subsection{Starch determination}

The $\%$ soluble carbohydrates were obtained by difference.

\subsection{Texture Analysis}

Texture was determined using a craft knife (P2 N) adapter attached to a TA.XT. plus Texture
Analyser (Stable Micro Systems, Surrey, UK). Six different but uniform $1 \mathrm{~cm}$ cubed sweet potatoes, with three replications, were used for determining the fermented OFSP hardness. Cutting force was measured against time at the following conditions: Test speed $0.5 \mathrm{~mm}$ per sec, trigger force $5 \mathrm{~g}$, post-test speed $10 \mathrm{~mm} / \mathrm{sec}$, and compression distance $5 \mathrm{~mm}$ using a suitable needle probe. The area under the curve (total work/energy to cut or toughness) was used as an indicator of grain hardness. The consumer sensory evaluation could not bring out any textural differences since the final product was homogenized to a smooth, uniform consistency, hence the use of the Texture Analyser (Stable Micro Systems, Surrey, UK). Homogenization took care of the differences in texture, appearance and shapes brought about by the fermentation process.

\subsection{The selection criterion}

The three samples were analysed for $\beta$-carotene and flavour profiling, and the one with the most $\beta$-carotene was selected for further lactic acid fermentation. Specifically, the Zapallo variety which had the highest quantity of $\beta$-carotene was selected for this process. The $\beta$-carotene content of Zapallo was sufficient to enable its following in the food matrix.

\subsection{Preparation of $L$. plantarum (MTCC 1407) Culture}

The L. plantarum (MTCC 1407) culture was procured from the Institute of Microbial Technology, India. The bacterial cultures were of direct vat set type thus eliminating need for the use of Mann-Rogassa-Sharpe (MRS) Agar slants as would be necessary for lyophilized forms. The bacterial culture was grown on MRS Agar medium to test for potency and then counted to determine the viable cells. The culture was kept at $30^{\circ} \mathrm{C}$ for 24 hours and then extended to 36 hours. There was observed rapid growth on the MRS Agar plates. The cells were examined for staining, catalase and oxidase tests. 


\subsection{Preparation of Starter Culture}

One hundred grams of good quality sweet grapes (from Yatta) were selected and washed under running tap water. The grapes were mashed in a Mixer-cum Grinder (TTK Prestige Ltd., Bangalore, India) and the juice extracted using a juice squeezer. The volume of juice, filtered through cotton cheesecloth, was measured and an equal volume of water added. The mixture was boiled for 12 min on a hot plate and then cooled to room temperature. After cooling, the grape juice was inoculated with the L. plantarum culture and incubated at $30^{\circ} \mathrm{C}$ for $24 \mathrm{~h}$ to produce the active starter culture. A viability test was carried out by inoculating the culture onto a sterile De Man Rogosa Agar plate.

\subsection{Pickling of Sweet Potato}

The roots were prepared by hand washing, peeling and then cutting into small cubes (approximately $1 \mathrm{x} 1 \mathrm{~cm})$. The cubes were blanched at $70^{\circ} \mathrm{C}$ for $10 \mathrm{~min}$. $140 \mathrm{~g}$ of the blanched sweet potato cubes were dispensed into $500-\mathrm{ml}$ plastic jars. A brine solution at five different concentrations $(2,4,6,8$ and $10 \% \mathrm{w} / \mathrm{w}) .300 \mathrm{ml}$ of the prepared brine solution was then added to each bottle. $7 \mathrm{ml}$ of the starter culture (1 $\mathrm{x} 10^{7} \mathrm{cfu} / \mathrm{ml}$ ) was inoculated into each bottle and then each bottle was capped tightly. One negative control sample, without salt and Lactobacillus plantarum, was maintained. The entries were randomized in three replications.

The sweet potato brine solutions mixture was fermented on the laboratory bench at room temperature. The fermentation was allowed to continue for 28 days for the pickle to season before a preservative, potassium metabisulphite (100 $\mathrm{mg} / \mathrm{g}$ ) was added to prevent the growth of undesirable microorganisms such as the salt-tolerant fungi-Aspergillus species. The flow diagram for this process is shown in Figure 1.

\subsection{Treatment of the control}

After preparation to the point of blanching, no salt or L. Plantarum was used on the negative control. The cut sample was dispensed into a $500 \mathrm{ml}$ jar and distilled water added. Analytical data for, $\mathrm{pH}$, TA and $\beta$-carotene content was collected on day 2 and then at intervals of 7 days from day zero to end of the $28^{\text {th }}$ day of fermentation.

\subsection{The biochemical analysis of the lacto pickles}

Sweet potato cubes and brine (1:5 ratio) were homogenized in a Mixture-cum Grinder and the equilibrated mash used for biochemical analyses. Analytical data was collected for $\mathrm{pH}$, starch, total sugar, $\beta$-carotene content, TA and LA.

\subsection{The $\mathrm{pH}$ of fermented product}

$\mathrm{pH}$ values were determined by a Milwaukee SM $101 \mathrm{pH}$ meter \pm 0.02 (smart $\mathrm{pH}$ meter), with a temperature compensation technique, using glass electrode. The $\mathrm{pH}$ meter was first calibrated with freshly prepared buffer solutions of 7.0 and 4.0 before use.

\subsection{Titratable acidity}

The percentage (\%) titratable acidity was determined by titrimetry. $10 \mathrm{ml}$ of sample was titrated against $0.1 \mathrm{~N}$ Sodium hydroxide, with phenolphthalein indicator, to an endpoint according to AOAC (2005). The \% titratable acidity was determined using the following formula:

$$
\% \mathrm{TA}=\mathrm{Vol} \text { of } \mathrm{NaOH} \times \mathrm{N} \text { of } \mathrm{NaOH} \times 9
$$

\subsection{Lactic acid (LA)}

LA content was determined using a conversion factor as reported by Pearson and the data expressed as equivalent of $\mathrm{LA} \mathrm{g} / \mathrm{kg}$ roots. It involved the multiplication of titratable acidity by the appropriate factor of $0.009008 \mathrm{~g} \mathrm{C}_{3} \mathrm{H}_{6} \mathrm{O}_{3}$

\subsection{Starch and total sugar}

Starch and total sugar contents were estimated by the procedures reported by Mahadevan and 
$18 \mid$ Oloo et al.

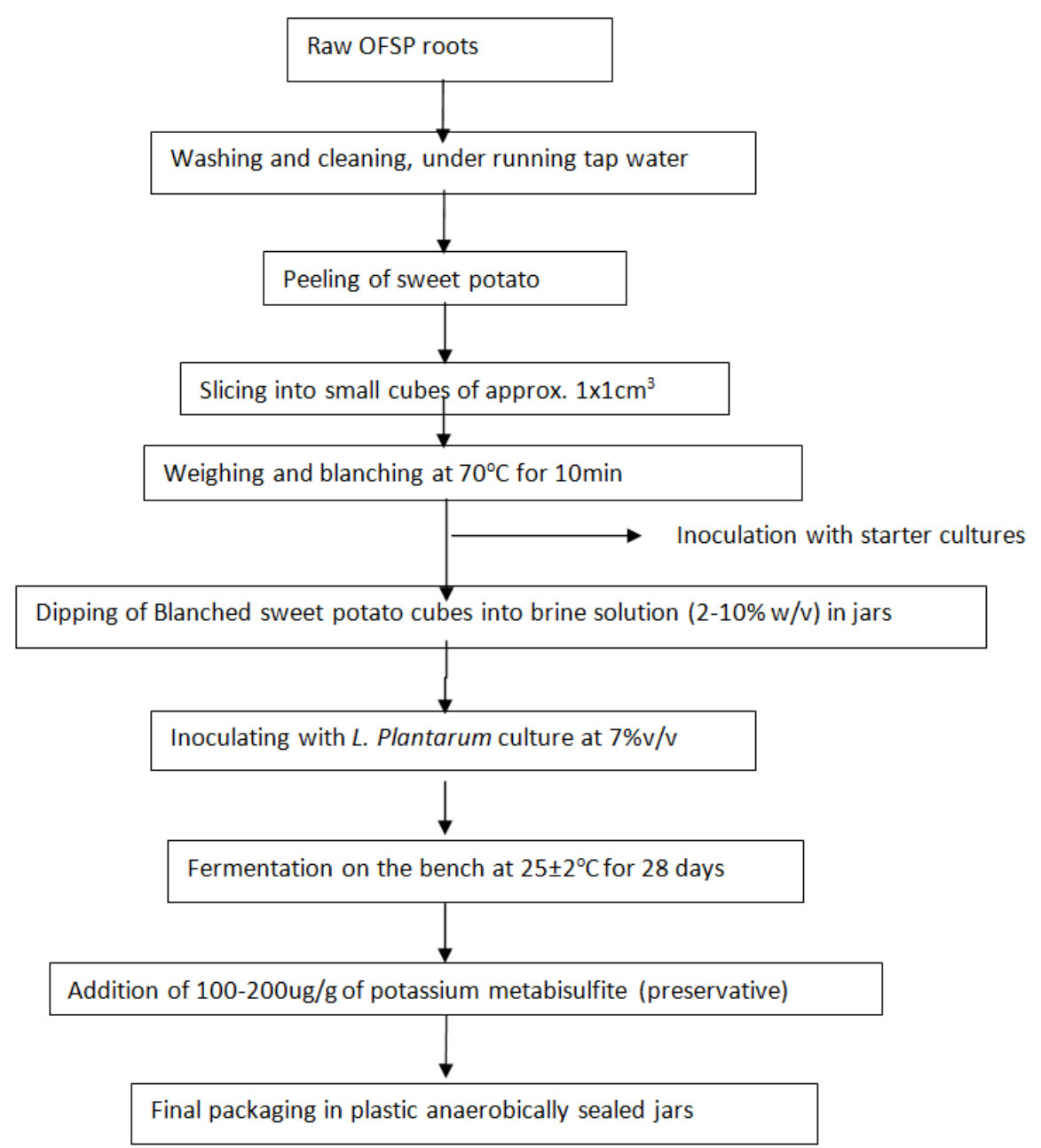

Figure 1: Flow diagram for the fermentation of Lacto-pickles. Adopted with modification from Panda, Parmanick, and Ray (2007) 
Sridhar (1993), and the values expressed in $\mathrm{g} / \mathrm{kg}$ roots. The diluted samples were mixed with $0.05 \mathrm{ml}$ of $80 \%$ phenol. $5 \mathrm{ml}$ of concentrated sulphuric acid was then added to the mixture which was vortexed and the absorbance read at 490nm.

\subsection{Determination of $\beta$-Carotene in fermented sample}

This was conducted according to the procedure described in 2.10 .

\subsection{Determination of Texture of fermented pickles}

The same procedure as described in 2.13 was used.

\subsection{Sensory Evaluation and flavour profiling}

A semi-trained panel was involved in flavour profiling of the basic attributes of the product. The product was then subjected to affective sensory test according to the procedure below: Sensory attributes (taste, aroma, flavor, color/appearance and aftertaste) were evaluated using a 5-point hedonic scale (where $1=$ dislike extremely and $5=$ like extremely) by an 18 member panel (gender: 10 women, 8 men; age group: 20-40) selected from local people and staff from the Food Science and Nutrition departments atf Egerton University, Njoro. The samples were served in polypropylene transparent cups, which had been labeled with a 3-digit random number. Questionnaires and water to rinse the mouth between each tasting session were provided. Panelists were advised to have at least 15 seconds break before tasting the next sample.

Prior to evaluation, a session was held to familiarize the panelists with the product. The panel was then asked to read through the questionnaires and to understand the meaning of each attribute (texture, taste, aroma, flavor, color/appearance and aftertaste) to avoid any misinterpretation (Kilcast \& Subramaniam, 2000). The tasters were not allowed to discuss their findings with one another during the evaluation session. Another set of lacto-pickles were evaluated, as a replication, the following day. Sensory evaluation data was presented as a mean score for the 18 panelists. A standard t-test was used to test the statistical significance $(\mathrm{p}<0.05)$ of the differences observed between the scores of the two tests.

\subsection{Statistical analysis}

Statistical analysis was performed using the SASJMP Software version 9.0. One-way analysis of variance (ANOVA) and least significant difference was used for statistical comparison.

\subsection{Experimental design}

The experimental design was the completely randomized design (CRD) and mean comparison using the least significant difference procedure. The measured value of a parameter was the mean plus the treatments of different brine concentrations and day of fermentation.

Model: $\mathrm{y}_{i}=\mu+\tau_{i}+\varepsilon_{i j}$

$y_{i}=$ individual observation of the $\mathrm{i}^{\text {th }}$ treatment and the $\mathrm{j}^{\text {th }}$ replication

$\mu=$ is the overall mean

$\tau_{i}=$ the $\mathrm{i}^{\text {th }}$ treatment effect

$\varepsilon_{i j}=$ the random error component

\section{Results and discussion}

\subsection{Results of the proximate analysis values of OFSP varieties}

The proximate analysis values for Zapallo, $\mathrm{Ny}-$ athiodiewo and SPK004/06 varieties are presented in Table 1. Moisture, Dry Matter (DM), Protein, Ash, crude fiber and fat contents were reported as \% w/w, while, Total sugars, Starch, Ascorbic acid, Iron, Zinc and $\beta$-carotene contents were presented in $\mathrm{mg} / \mathrm{kg}$. The reported values for weights and $\beta$-carotene are on a dry weight basis, whilst the rest are reported on a fresh weight basis. 
Retinol activity equivalence (RAE) is $12 \mu \mathrm{g}$ $\beta$-carotene $=1 \mu \mathrm{g}$ retinol $=1 \mu \mathrm{g}$ RAE (Trumbo, Yates, Schlicker, \& Poos, 2001; US IOM, 2001). The recommended daily allowance was pegged at $400 \mu \mathrm{g}$ RE for preschool children (FAO/WHO, 1988).

The moisture content values are presented in Table 1. SPK004/06 had the highest moisture content at $88.74 \%$. It was followed by Zappalo at $79.7 \%$ and Nyathiodiewo at $70.47 \%$. These results demonstrate a similarity to those reported by Hagenimana, Carey, Gichuki, Oyunga, and Imungi (1998), who reported values of $75.7 \%$ for Zappalo and $67.7 \%$ for SPK004/06. The literature search, however, did not turn up any previous moisture content measurements for Nyawo (Nyathiodiewo), a local variety. In a different study conducted by Nshimiyimana (2012), he reported a value of $78.99 \%$ moisture content on the varieties he was working with. The difference in these values may be related to the differences in agro-ecological zones where the crops were grown (Vimala, Sreekanth, Binua, \& Wolfgang, 2011). Dry matter content of sweet potatoes has been shown to have a positive correlation with the consumer preference of the different sweet potato varieties. The dry matter values indicate that Nyathiodiewo had the highest amount of Dry matter at $29.53 \%$ followed by Zapallo, and SPK004/06 at $20.3 \%$ and $11.26 \%$ respectively (Table 1). The result of the dry matter content for Zapallo $20.3 \%$ was similar to that reported by Tomlins, Owori, Bechoff, Menya, and Westby (2012) at between $22.28 \%$ and $36.5 \%$. Even though the reported value of $20.3 \%$ was lower than the range obtained by Tomlins et al. (2012), the values of dry matter content for Nyathiodiewo also agree with the findings of Rodriguez-Amaya, Kimura, Institute, and de Agricultura Tropical (2004) and Ndolo, Nungo, R.E., and Agili (2007) who reported dry matter ranges for different varieties between $21.4 \%$ and $38.7 \%$, while Tewe (1994) reported DM values of between 17.8 and $38.2 \%$. For SPK004/6, the reported value of $11.26 \%$ differed significantly from the values reported by Tewe (1994) and Rodriguez-Amaya et al. (2004). This low Dry matter (DM) content may have been due to the prevailing rainy conditions during the time of harvesting or a combination of any of the fac- tors. These factors could include: the selection of OFSP with higher dry matter content, environmental (weather, soil, farming practices), and maturity (Tomlins et al., 2012). Dry matter is a key criterion in determining the nutritive value of a food product. In sweet potatoes, DM is positively correlated with the starch content. It also determines the amount of the other food elements, with the exception of water (Kaguongo, Ortmann, Wale, Darroch, \& Low, 2012). Consumers in Africa prefer high dry matter content sweet potato roots (Kapinga \& Carey, 2003). According to a study conducted in parts of Western Kenya, Kaguongo et al. (2012) established that the farmers were willing to adopt new cultivars of sweet potatoes provided they had high or sufficient quantities of starch (dry matter) and if they were equally low in fibre. Unfortunately, the OFSP varieties of high $\beta$-carotene content tend to have low dry matter content. Breeding efforts and programmes have focused on breaking this correlation between dry matter content and $\beta$-carotene content. Of the three varieties analysed, there were significant differences in the dry matter and moisture content. Many studies report varying results based on variety, geographical area where the crop is grown, and the agro ecological conditions of their growth (Hart \& Scott, 1995; Xin et al., 2008).

Table 1 shows that the values of protein among all the different varieties ranged from $3.20 \%$ to $3.45 \%$. Nyathiodiewo had the highest value at $3.45 \%$, with Zapallo and SPK004/06 at 3.34\% and $3.20 \%$ respectively. These values agree with values reported by Ukpabi, Ekeledo, and Ezigbo (2012). Being a low supplier of protein in the diet, many studies have not exploited the values of protein in the sweet potatoes (Ndolo et al., 2007; Tomlins et al., 2012; Bengtsson et al., 2008).

The value of the fat content was reported at $2.1 \%, 3.21 \%$ and $3.16 \%$ for Zapallo, $\mathrm{Ny}-$ athiodiewo, and SPK004/6 respectively (Table, $1)$. These values were similar to those reported by Emmanuel et al. (n.d) who reported a crude fat value of $1.15 \%$ for OFSP, Kwazikumwe. Their reported value of fat content on a yellow variety, Caceapedo was $0.6 \%$. Even though these values were lower compared to those reported in this study, the variation may have been due to 
Lactic Acid Fermentation of Orange Fleshed Sweet Potatoes $\mid 21$

the varietal differences and the differences in the agro ecological conditions of growth. However, the recorded values for the three varieties are significantly higher than those values reported by Ukpabi et al. (2012) when they analysed some selected Nigerian OFSP varieties. The lack of fat in the diet is one of the contributing factors to vitamin A deficiency (VAD) (Carey et al., 2012). Generally, a dietary fat of more than $6 \%$ is desirable in enhancing $\beta$-carotene's bio efficacy. From the results in Table 1, all the dietary fats of the varieties shown were lower and ranged from 2.1 to $3.1 \%$. However, this could be enhanced through fermentation and processing as fried products. The values for carbohydrates/starch for Zapallo, Nyathiodiewo and SPK004/06 are reported in Table 1 . The SPK004/6 had the highest value of carbohydrate at $11.79 \mathrm{~g} / \mathrm{kg}$ followed by Zapallo and lastly, Nyathiodiewo at $6.94 \mathrm{~g} / \mathrm{kg}$ and $5.05 \mathrm{~g} / \mathrm{kg}$ respectively. In a related study on OFSP, Kwezikumwe, Emmanuel, Vasanthakaalam and Mukwantali et al. (n.d) reported a value of $7.65 \mathrm{~g} / \mathrm{kg}$ which is similar to the reported value in this work. The results were also in congruence with the carbohydrate values of $60.14 \mathrm{~g} / \mathrm{kg}$ on dry weight basis reported by Abdel-Gayoum and Abdel-Rahman (2012). Sweet potatoes are a good source of carbohydrates yet have very low calories (141cal/gram) according to Konczak, Okuno, Yoshimoto, and Konczak (2004).

The three varieties had dietary fiber ranging from 2.55 to $3.54 \%$ as reported in Table 1 . Nyathiodiewo had the highest value at $3.54 \%$, followed by SPK004/6 at $3.52 \%$ and Zapallo, with the least value of dietary fiber at $2.56 \%$. In a study involving selected Orange fleshed sweet potato varieties from Nigeria, Degras et al. (2003) found the dietary fiber to range from 3.4 to $5.9 \%$. The results are also similar to the values reported by Abdel-Gayoum and AbdelRahman (2012) at $11.31 \%$ on dry weight basis. Dietary fiber is an important component of orange fleshed sweet potatoes. In fact, sweet potato ranks among the top contributors of dietary fiber and other nutrients in the diet according to Cummings (2005) and Farinu and Baik (2007). Even though the presence of dietary fiber has been associated with flatulence among some consumers, dietary fiber is still very important in enhancing bowel movement and cleansing of the gastrointestinal tract . In addition, dietary fiber is important in reducing blood cholesterol (Chukwu, Nwadike, \& Nwachukwu, 2012).

The SPK004/6 variety was observed to possess the highest value of Total Ash content (7.08\%) while Nyathiodiewo had the least $(4.29 \%)$. Zapallo's ash content was reported at $5.69 \%$ (Table 1). (Abdel-Gayoum \& Abdel-Rahman, 2012) reported a Total Ash value only for Zapallo at $12.05 \%$ on dry weight basis, which is similar to the value reported for Zapallo in this work. In separate work dealing with Kwezikumwe (an OFSP variety), Emmanuel et al. (n.d), reported a Total Ash value of $4.7 \%$ which was also very similar to the value reported in this work. Sweet potatoes are a good source of several minerals including Iron and Zinc, among others (Hussain, Zeb, Shakir, \& Shah, 2008).

Iron and Zinc are among the most important minerals whose deficiencies are suffered by children in Sub Saharan Africa and the developing nations in Asia. The proximate values of Zinc and Iron for the three varieties are reported in Table 1. The values of Iron for the three Orange fleshed sweet potato varieties were reported as $84 \mathrm{mg} / \mathrm{kg}, 87 \mathrm{mg} / \mathrm{kg}$, and $86 \mathrm{mg} / \mathrm{kg}$ for Zapallo, Nyathiodiewo, and SPK004/06 respectively. The values for Zinc were reported as $18 \mathrm{mg} / \mathrm{kg}, 25 \mathrm{mg} / \mathrm{kg}$, and $25 \mathrm{mg} / \mathrm{kg}$ for Zapallo, Nyathiodiewo, and SPK004/06 respectively. According to World Food Programme WFP (2002), Recommended Nutrient Intake (RNI) for preschool children was $10.3 \mathrm{mg} /$ day for Zinc and $13 \mathrm{mg} /$ day for Iron from foods with low viability in both cases. The results show that OFSP can alleviate the deficiency of Zinc and Iron in populations in developing countries and more specifically among pre-school, school going children, and pregnant women (Hagenimana \& Low, 2000). Hence, a regular OFSP diet can also significantly reduce the need for Iron supplementation among pregnant women WFP (2002).

As for Zinc, the WFP report specifies that most infant food formulas have cereals or vegetable proteins that may inhibit Zinc absorption (WFP, 2002). This goes to illustrate that feeding children on OFSP will supply the Recommended Nutrient Intake (RNI) of Zinc and may reduce the need to feed them on formulations with sub- 
stances such as phytate that could easily inhibit Zinc's absorption (WFP, 2002).

The values for Ascorbic acid (vitamin C) for the three varieties are reported in Table 1 . Zapallo recorded the lowest value of Ascorbic acid at 2.8 $\mathrm{mg} / \mathrm{Kg}$ followed by SPK004/6 at $3.3 \mathrm{mg} / \mathrm{Kg}$, and the highest value of Ascorbic acid was recorded at $3.4 \mathrm{mg} / \mathrm{Kg}$ for Nyathiodiewo. Results reported by Abdel-Gayoum and Abdel-Rahman (2012) for Ascorbic acid for two Sudanese varieties were 65.70 and $60.08 \mathrm{mg} / 100 \mathrm{~g}$. This was significantly different from our reported value at between 28 and $36 \mathrm{mg} / 100 \mathrm{~g}$, but much higher than values reported by Chukwu et al. (2012) which were at $0.5 \mathrm{mg} / 100 \mathrm{~g}$. The levels of nutrients (especially vitamins) in food depend on natural sources of variation in the species, the nature of the soil, genetic diversity, seasonality (such as amount of moisture and sunlight available during critical times of growth), stage of maturity and effect of processing (Abdel-Gayoum \& Abdel-Rahman, 2012). Still, the values obtained demonstrate the reported importance of orange fleshed sweet potatoes in contributing to the recommended daily allowance (RDA) of Vitamin $\mathrm{C}$ in the diets of regular consumers -(Carey et al., 1998). In addition, the presence of Ascorbic acid will increase the bioavailability of Iron in the diet of its consumers.

\subsection{The variability in $\beta$-carotene content of the raw orange-fleshed sweet potato varieties}

The values of $\beta$-carotene content of the sweet potato varieties are reported in Table 1 . The Zapallo variety recorded the highest value of $\beta$ carotene at $170.02 \mathrm{mg} / \mathrm{g}$, followed by SPK004/06 at $5.06 \mathrm{mg} / \mathrm{g}$, and Nyathiodiewo at $0.31 \mathrm{mg} / \mathrm{g}$. The value of $\beta$-carotene from Zapallo was similar to the values reported by Bengtsson et al. (2008) of 108.1 to $265 \mathrm{mg} / \mathrm{g}$. They demonstrated very large variability in the values of $\beta$-carotene for different OFSP varieties grown at different locations or even those grown together. For this work, all the potatoes were harvested from the same location. Any differences noted must have been simply varietal. This view has been since supported by the work of Huang, Tanudjaja, and Lum (1999), K'osambo, Carey, Misra, Wilkes, and Hagenimana (1998), van Jaarsveld et al. (2006) and Tomlins et al. (2012). The value of $\beta$-carotene content was used as the selection criterion for the choice of Zapallo for tracing the effects of fermentation on the $\beta$-carotene of this variety. Due to the difficulty in totally extracting $\beta$-carotene from OFSP, and the serious changes in the level of $\beta$-carotene, following of the same over the given fermentation period required that the variety with the highest value was selected for the fermentation process.

From 20 different varieties analyzed by Takahata, Noda, and Nagata (1993), the $\beta$-carotene content was determined to vary from 11 to $266 \mathrm{mg} / \mathrm{kg}$ fresh weight basis. These results are similar to the ones reported in this study. In another study conducted by K'osambo et al. (1998) the variation in $\beta$-carotene for the 17 varieties analysed was reported to range from $<1$ to $80 \mathrm{mg} / \mathrm{kg}$, values that are also similar to the determinations in the current study. According to Hart and Scott (1995) some of the factors suggested for the significant variations include variety, maturity, post-harvest storage conditions, seasons and the portion of the root selected for the study. Orange fleshed sweet potatoes are therefore very good sources of $\beta$-carotene, which is the best remedy for VAD.

\subsection{The viability of the Lactobacillus platarum}

To assess the viability of starter culture ( $L a c$ tobacillus plantarum), the Microorganisms were cultivated in sterile MRS Agar, AR. (Himedia Laboratories Ltd. India) and incubated at 30$35^{\mathrm{O}} \mathrm{C}$ for 24 hours. The resulting growth of pure culture observed demonstrated the viability of the cells for use as starter culture. 
Lactic Acid Fermentation of Orange Fleshed Sweet Potatoes $\mid 23$

Table 1: Analysis of variance results for the proximate analysis values of OFSP varieties

\begin{tabular}{llllll}
\hline Constituent & Zapallo & Nyathiodiewo & SPK004/6 & SD & CV\% \\
\hline Moisture (\%) & $79.7^{b}$ & $70.47^{c}$ & $88.74^{a}$ & \pm 0.26 & 0.33 \\
Dry matter content (\%) & $20.3^{b}$ & $29.53^{a}$ & $11.26^{c}$ & \pm 0.26 & 1.29 \\
Protein (\%) & $3.34^{a}$ & $3.45^{a}$ & $3.20^{b}$ & \pm 0.07 & 2.13 \\
Fat (\%) & $2.10^{b}$ & $3.21^{a}$ & $3.16^{a}$ & \pm 0.10 & 3.59 \\
Starch/carb (\%) & $6.94^{b}$ & $5.05^{c}$ & $11.79^{a}$ & \pm 0.81 & 10.07 \\
Dietary fibre (\%) & $2.56^{b}$ & $3.54^{a}$ & $3.52^{a}$ & \pm 0.09 & 2.81 \\
Ash (\%) & $2.59^{b}$ & $3.57^{a b}$ & $3.49^{a}$ & \pm 0.90 & 15.89 \\
Fe (mg/Kg) & $84.00^{c}$ & $87.00^{a}$ & $86.00^{b}$ & \pm 0.00 & 0 \\
Zn (mg/Kg) & $18^{b}$ & $25^{a}$ & $25^{a}$ & \pm 0.00 & 0 \\
$\beta$-carotene (mg/Kg) & $170.02^{a}$ & $0.31^{c}$ & $5.06^{b}$ & \pm 0.64 & 4.25 \\
Ascorbic acid (mg/kg) & $2.8^{b}$ & $3.4^{a}$ & $3.30^{a b}$ & \pm 0.26 & 8.12 \\
Weights (g) & $491.63^{a}$ & $514.4^{b}$ & $167.15^{c}$ & \pm 2.64 & 1.26 \\
RAE/100g & $1416.83^{a}$ & $2.55^{b}$ & $42.15^{c}$ & \pm 2.64 & 4.25 \\
\hline
\end{tabular}

\subsection{The results from fermented OFSP samples at the beginning and end of the fermentation process}

The results indicate significant differences among all the parameters under study (Figure 2). The significant reduction among various analytical parameters over the period of fermentation is explained by the complexity of changes that occur in foods to bring about the desirable attributes in the final product. The $\mathrm{pH}$ ranged from 6.21 on the initial day to 3.27 by the final day, 28 . The decrease in $\mathrm{pH}$ was attributable to the increasing acidity due to the action of the lactic acid fermenters. In the process, the $L$. plantarum breaks down sugars and produces organic acids which contribute to increased acidity. The Lactic acid rose significantly $(\mathrm{P} \leq 0.05)$ from $0.03 \mathrm{~g} / \mathrm{kg}$ to $0.53 \mathrm{~g} / \mathrm{kg}$. Total sugar on the other hand was significantly increased from $2.23 \mathrm{mg} / \mathrm{kg}$ to 5.86 $\mathrm{mg} / \mathrm{kg}$ by end of fermentation period. This increase may be attributed to the breakdown of starch to simple sugars over the period of fermentation. Even though, Lactic acid is not the only acid produced, the results of Titratable acidity are expressed in terms of Lactic acid equivalent since this forms the predominant acid in fermented vegetables. The Titratable acidity rose from an initial level of 0.34 to $5.86 \mathrm{mg} / \mathrm{kg}$ over the fermentation period.

Total starch, on the other hand, was significantly reduced from $7.10 \mathrm{mg} / \mathrm{kg}$ to $1.3 \mathrm{mg} / \mathrm{kg}$ by end of the fermentation period (Figure 2). The decrease in starch may be due to the action of amylolytic activity of L. plantarum (Giraud, Brauman, Keleke, Lelong, \& Raimbault, 1991). During fermentation, starch and other carbohydrates are converted to simple sugars and further to lactic acid, carbon dioxide, and other organic acids (Panda et al., 2007). The simple sugars are utilized by lactic acid fermenters during their metabolism and this may have reduced the texture of the OFSP.

Texture is a function of the interaction of the major macromolecules of carbohydrates, fat, protein and water within the food matrix (Kumar \& Mishra, 2004). There was a significant difference in texture as measured by the Texture analyser (Figure 2). The initial texture value was $0.5 \mathrm{~N} / \mathrm{m}^{2}$ and this was reduced significantly to $0.3 \mathrm{~N} / \mathrm{m}^{2}$ after the fermentation period. During processing, there was blanching for 10 minutes at $70^{\circ} \mathrm{C}$ which may have resulted in breakdown of starch to amylose and amylopectin fractions. In addition, the fermentation process breaks down some of the starch to the above mentioned components, which are further acted upon by microorganisms to produce simple sugars (Panda \& Ray, 2007), (and Panda et al. (2007)).

There was a significant reduction in the concentration of Ascorbic acid from 2 to $0.53 \mathrm{mg} / \mathrm{kg}$ over the 28 days of the fermentation process (Figure 2). Most of this reduction may be due to the 
blanching of OFSP at $70^{\circ} \mathrm{C}$ since ascorbic acid is highly heat labile. Sweet potato roots are considered not only a good source of Phenolic compounds but also possess high amounts of Ascorbic acid and sugars. Cooking has been known to cause loses in water soluble vitamins, particularly the heat labile, Ascorbic acid. However, as a preservation method, fermentation has the potential to retain this vitamin within the food matrix.

\subsection{Effect of fermentation on various biochemicals over the fermentation period}

Figure 3 presents the trend of changes in Lactic acid, $\mathrm{pH}$ and Titratable acidity over the fermentation period. The final $\mathrm{pH}$ value of the fermented product was reported at 3.21 while the variation in $\mathrm{pH}$ due to brine concentration was reported to be between $\mathrm{pH} 4.82$ to 4.71 . There was a sharp decline in $\mathrm{pH}$ from day 0 to day 7 . On the other hand, the Lactic acid concentration increased steadily over the fermentation period. The Titratable acidity levels picked up after the second day of fermentation and continued to rise throughout the fermentation period. The amount of lactic acid increased from $0.0307 \mathrm{mg} / \mathrm{Kg}$ to $0.529 \mathrm{mg} / \mathrm{kg}$ over the fermentation period. Optimal $\mathrm{pH}$ for fermented vegetables has been reported between 3.8 and 4.5 (Adams \& Nicolaides, 1997). Decrease in $\mathrm{pH}$ during fermentation is usually due to accumulation of organic acids, especially lactic acid (Arvanitoyannis, 2006; Kim, Min, Lee, \& Ji, 2000). This is often accompanied by a decrease in starch and sugar as a result of their utility by Lactobacillus plantarum for growth and metabolism (Gardner, Savard, Obermeier, Caldwell, \& Champagne, 2001). The values of Titratable acidity increased from $0.34 \mathrm{mg} / \mathrm{kg}$ to 5.88 $\mathrm{mg} / \mathrm{kg}$ over the period of fermentation. Titratable acidity (TA) is an important parameter in following the progress of a fermentation process. TA is either inherent or induced as a result of the converstion of sugars to lactic acid by the lactic acid cultures. Of the many titratable acidities, LA is the main organic acid produced by action of Lactobacilli (Gardner et al., 2001). As a starter culture in the fermenation of OFSP, L.plantarum is responsible for developed acidity. It is important to have a quick and steady rise in titratable acidity, particularly in the first week of a fermentation process. This induced acidity is responsible for inhibiting any spoilage microorganisms. The titratable acidity is often expresed as \% Lactic (AOAC, 2005).

Panda et al. (2007) noted that fermented vegetables have probiotic characteristics. Consequently, they have enjoyed a renewed interest and increase in demand. Fermented foods are considered a unique alternative to people intolerant to lactose or who have allergies towards milk protein (Kaur \& Kapoor, 2001). Lactic acid starter culture provides consistency and reliability of performance in fermentation processes (Troung, McFeeters, \& Lanier, 2004). L.plantarum has been the dominant microorganism isolated from most fermented vegetables (Molin, 2008; Montet, Loiseau, \& Zakhia-Rozis, 2006). Application of fermentation to processing of OFSP is seen to provide several advantages. The orange and purple fleshed varieties are believed to possess pigments which have been considered as nutraceuticals (Kaur \& Kapoor, 2001). For optimal results, juice extraction is critical in fermentation processes (Demir, Acar, Sarığlu, \& Mutlu, 2001). Orange Fleshed sweet potato (OFSP) cell wall has cellulose, hemicellulose, and pectin which may obstruct juice extraction during the fermentation process. Hence pectinase enzyme has been used in some studies to improve juice extraction for better fermentation results (Panda \& Ray, 2007).

\subsection{Results of the variations in LA, TA, pH, Total sugar, Starch, Texture, Ascorbic acid and $\beta$-carotene at varying brine concentrations over the fermentation period}

Table 2 shows the variation in the analytical parameters at different brine concentrations and with days of fermentation. There was no significant difference found in $\beta$-carotene concentration amongst OFSP fermented samples at the 


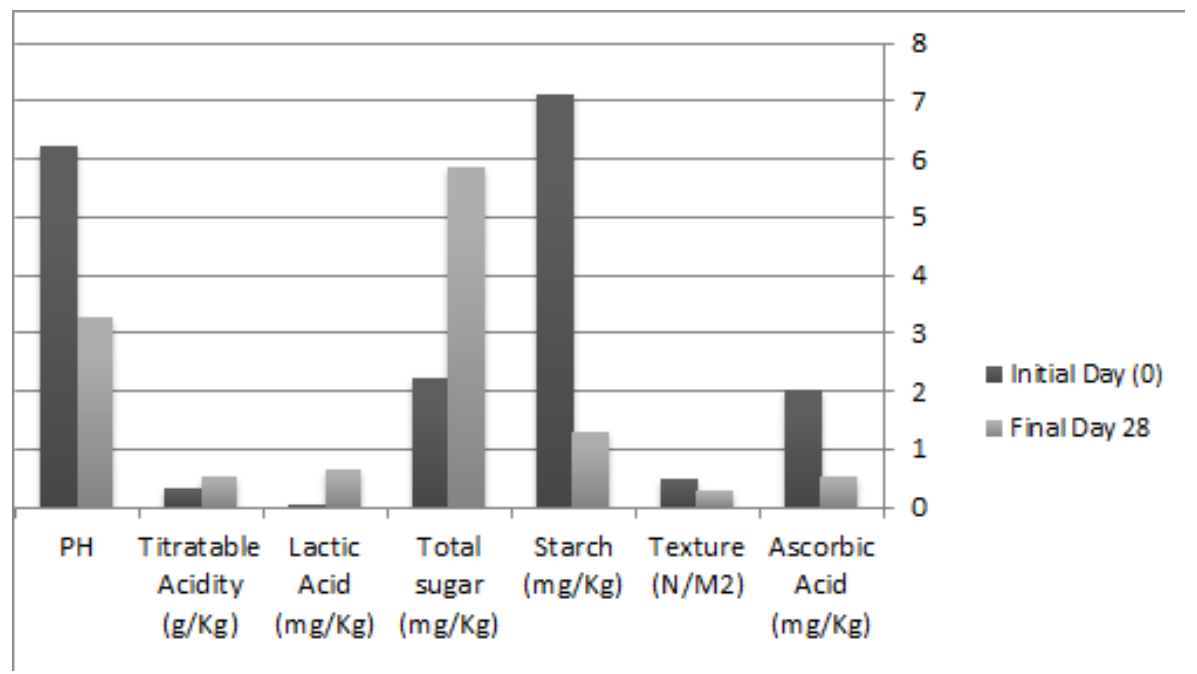

Figure 2: Biochemical attributes for day 0 and day 28 of the fermentation period

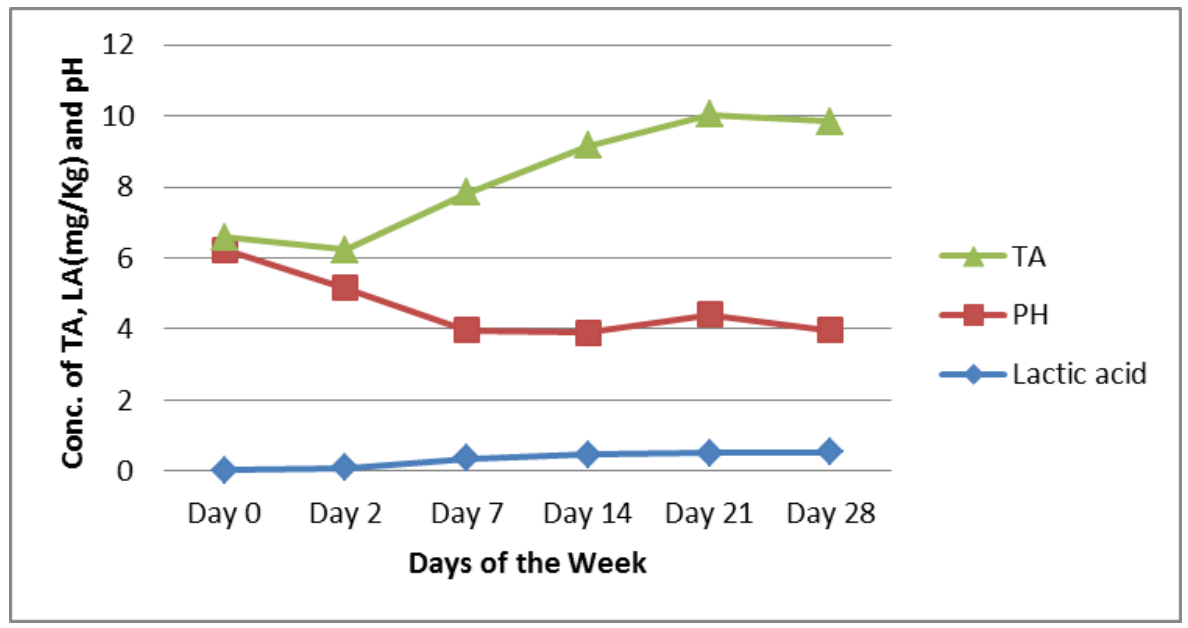

Figure 3: Changes in TA, LA and $\mathrm{pH}$ over the fermenation period 
different levels of brine concentration $(\mathrm{P} \leq 0.05)$. However, products with 4, 6 and $10 \%$ levels of brine recorded the highest $\beta$-carotene concentration followed by the one with $8 \%$. The control and $2 \%$ brine samples recorded the lowest values of $\beta$-carotene. This shows an interaction with day of fermentation rather than any direct effect of salt itself. However, these results also reveal a potential for process optimization using appropriate levels of salt. Notably, L. plantarum is a salt tolerant bacterial species and has been reported to tolerate salts of more than $4 \%$. This makes it the most viable option in fermentation of pickled products where salt plays a selective and preservative role (Rajendran \& Ohta, 1998).

\subsection{Effects of lactic acid fermentation on the $\beta$-carotene content of OFSP}

There was a significant difference reported on the concentration of $\beta$-carotene between the first day and the second day of fermentation. The $\beta$-carotene value varied from $170.02 \mathrm{mg} / \mathrm{Kg}$ to $156.49 \mathrm{mg} / \mathrm{Kg}$ over the period of fermentation (Figure 4). The slight reduction may be an indication of $\beta$-carotene loss due to blanching at $70^{\mathrm{O}} \mathrm{C}$ for 10 minutes. $\beta$-carotene is not stable at temperatures between $65-70^{\circ} \mathrm{C}$ according to Yamakawa and Yoshimoto (2001). Blanching was however necessarry to kill any pathogenic microorganisms which would contaminate the stater culture. Inspite of the differences reported above, the resulting retention (93.97\%) was still the lowest reported value achieved by any other processing technique. More on this aspect is discussed in detail within the section on the effects of LA fermentation on $\beta$-carotene.

In Table 2, the impact of the different brine concentrations on $\beta$-carotene values indicate no significant difference at $\mathrm{P} \leq 0.05$. White or yellow fleshed sweet potato have minimum $\beta$-carotene and to achieve the RDA of $\beta$-carotene would demand consumption of impractically large quantities of sweet potatoes. On the contrary, OFSP sweet potatoes have substantial amounts of $\beta$ carotene. This study also confirms that the amount of $\beta$-carotene in OFSP is significantly retained even after fermentation (93.74\%). Even small quantities of OFSP (100g) may contain 300-3000 $\mu \mathrm{g} / 100 \mathrm{~g} \beta$-carotene per fresh weight. This will easily satisfy the RDA while serving as a good source of other vitamins and nutrients as well (Carey et al., 2012).

Food processing, drying and storage have been previously reported to have a major effect on $\beta$ carotene retention because of the nature of unsaturated, unstable carotenoids that are easily degraded by light, oxygen, ultra-violet heat, and heating leading to significant losses (RodriguezAmaya et al., 2004). It is therefore essential to optimise Orange Flesh Sweet potato (OFSP) processing conditions in order to achieve products with high nutritional quality (Jackobsen, 2011). The reduction effect of boiling on $\beta$ carotene content of sweet potatoes was reported as early as 1980s (Haralampu \& Karel, 1983). In some pioneering studies regarding the effect of fermentation on $\beta$-carotene, Panda et al. (2007) reported that $\beta$-carotene remained more or less the same after fermentation, i.e. no significant difference was reported. Even though the current study recorded significant difference between initial values of $\beta$-carotene and the final, the process resulted in much higher retention than the other methods of preparing OFSP available.

\subsection{The microbial acceptability of fermented OFSP}

At the end of the fermentation process the OFSP samples were analysed for microbial contamination as the safety of food must be guaranteed at the time of consumption. The tests were carried out for coliform and other pathogenic bacteria. The results showed that there were no coliforms. Fermentation is a novel preservation process where the low $\mathrm{pH}$ and high acid content are credited with the microbial integrity of the fermented products (Panda et al., 2007).

\subsection{The Effects of fermentation on the Sensory profile and consumer acceptability}

The sensory evaluation results for the fermented samples are presented in Table 3. For flavor, the 
Lactic Acid Fermentation of Orange Fleshed Sweet Potatoes $\mid 27$

Table 2: ANOVA results for the variations in LA, TA, pH, Total sugar, Starch, Texture, Ascorbic acid and $\beta$-carotene in fermented samples at different brine concentrations

\begin{tabular}{llllllll}
\hline & Control & $\mathbf{2 \%}$ & $\mathbf{4 \%}$ & $\mathbf{6 \%}$ & $\mathbf{8 \%}$ & $\mathbf{1 0 \%}$ & SD \\
\hline Lactic acid & $0.378^{b}$ & $0.365^{c}$ & $0.404^{a}$ & $0.189^{d}$ & $0.195^{d}$ & $0.144^{e}$ & \pm 0.0 \\
PH & $4.82^{a}$ & $4.75^{b}$ & $4.715^{c}$ & $4.72^{f}$ & $4.710^{f}$ & $4.715^{e / c}$ & \pm 0.0 \\
Tot sugar & $1.32^{d}$ & $1.38^{c}$ & $1.456^{b}$ & $1.452^{b}$ & $1.458^{b}$ & $1.57^{a}$ & \pm 0.02 \\
TA & $4.208^{b}$ & $4.05^{c}$ & $4.49^{d}$ & $2.083^{d}$ & $2.167^{d}$ & $1.6^{d}$ & \pm 0.09 \\
Starch & $7.1035^{a}$ & $3.614^{b}$ & $3.609^{b}$ & $3.586^{b}$ & $3.626^{b}$ & $3.6411^{b}$ & \pm 0.40 \\
Texture & $0.407^{a b}$ & $0.402^{a b c}$ & $0.37^{b c}$ & $0.36^{c}$ & $0.44^{a}$ & $0.42^{b}$ & \pm 0.03 \\
Ascorbic acid & $1.605^{e}$ & $1.625^{d}$ & $1.715^{a}$ & $1.696^{b}$ & $1.65^{b}$ & $1.70^{a b}$ & \pm 0.01 \\
$\beta$-carotene & $156.29^{a}$ & $156.06^{a}$ & $166.75^{a}$ & $167.717^{a}$ & $164.25^{a}$ & $168.43^{a}$ & $\pm 10.17 \mathrm{~s}$ \\
\hline
\end{tabular}

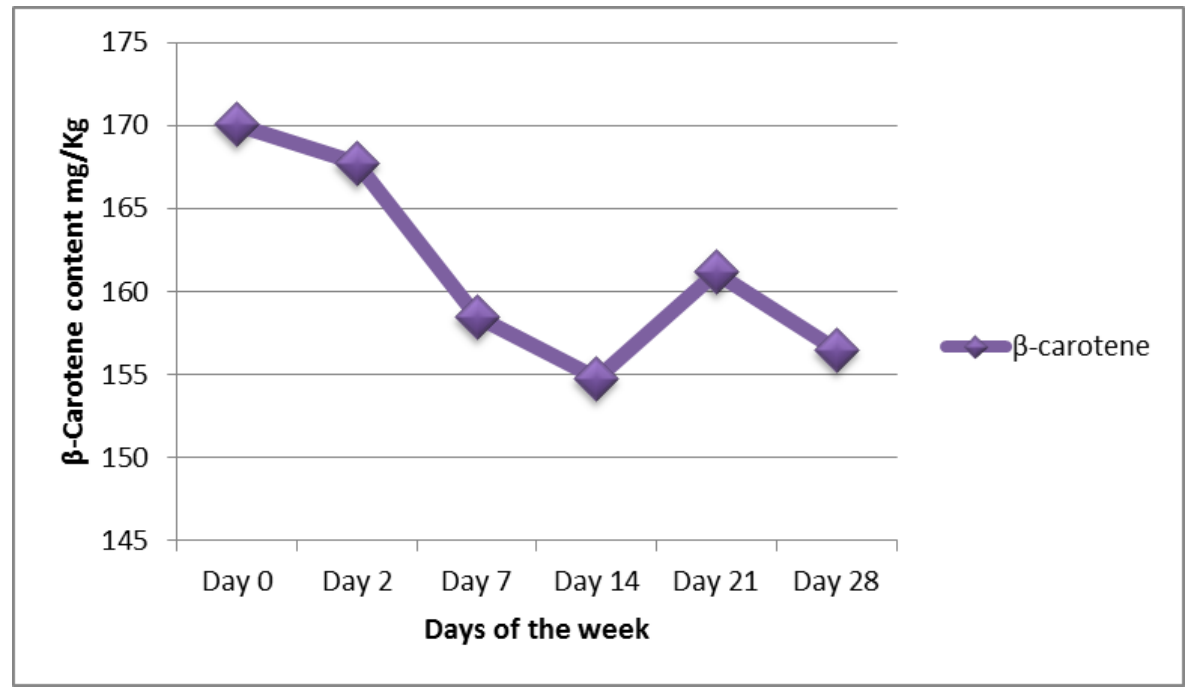

Figure 4: Changes in $\beta$-carotene over the fermentation period

Table 3: Sensory evaluation results for the fermented samples at different brine concentrations

\begin{tabular}{llllllll}
\hline & $\mathbf{0 \%}$ & $\mathbf{2 \%}$ & $\mathbf{4 \%}$ & $\mathbf{6 \%}$ & $\mathbf{8 \%}$ & $\mathbf{1 0 \%}$ & SD \\
Flavour & $2.14^{a b}$ & $2.14^{a b}$ & $2.3^{a}$ & $2.3^{a}$ & $1.93^{a b}$ & $1.5^{c}$ & \pm 1.0 \\
Taste & $2.5^{a}$ & $2.6^{a}$ & $2.6^{a}$ & $2.7^{a}$ & $2.3^{a}$ & $2.5^{a}$ & \pm 0.93 \\
General Appearance & $2.5^{a}$ & $2.5^{a}$ & $2.2^{a}$ & $2.14^{a}$ & $2.0^{a}$ & $2.3^{a}$ & \pm 1.02 \\
\hline
\end{tabular}


panellists' scores ranged from 2.3 to 1.5 , on a hedonic scale of 0 to 5 , indicating that they did not like the products. This may be because Kenyan Africans do not have a palate for pickles. In a study conducted by (Panda et al., 2007), panellist's responses with regard to flavor of lactopickles was reported as 3.2. This test score was, however, significantly different from lactopickles, with a10\% added sugar concentration, which had a reported score of 4.5. This result suggests that the consumer response to the lactopickles under study may have been greatly enhanced by adding an acceptable amount of sugar. Evidently, most panellists in their comments reacted to the high level of salt, which may have been masked by the additional sugar. Furthermore, the additional sugar would provide more substrate for L.plantarum metabolism, leading to a product with more physiological and microbial integrity.

In other studies, addition of sugar cane juice or sucrose had been reported to positively influence the response of consumers. This would be three pronged approach. First, it would provide more substrate for the action of Lactobacillus plantarum. Second, it would lead to a quicker rise in the LA content and finally, the sweetness would increase consumer acceptability. For increased acceptability, sugar cane at $10 \%$ can be added (Panda et al., 2007). Coupled with the ability of the fermentation process to retain significantly the amount of $\beta$-carotene in fermented samples, this would reduce VAD among its regular consumers.

The panellists preferred both the taste and flavour of the products with 4 and $6 \%$ brine. Products with $8 \%$ and $10 \%$ brine were significantly disliked on both flavour and taste. It was evident that increasing the amount of salt beyond $6 \%$ was disagreeable to most panellists. The $8 \%$ and $10 \%$ fermented samples reported the lowest scores on flavor. This was, however, different from the results reported by Panda et al. (2007), and Panda and Ray (2007) in which their panellists preferred lacto-pickles with 8 and $10 \%$ brine or salt. Regarding taste, the most preferred was also the one with $6 \%$ salt followed by 4 and then $2 \%$. However, the panellist's scores for all these products were not significantly different from the control. There was, however, no significant dif- ference in the test scores on taste at $\mathrm{p}<0.05$ level of significance. The panellist's scores also showed no significant difference in their preference for the appearance of the various sweet potato samples processed by lactic acid fermentation. The control received the highest score for appearance, followed by $2 \%$ and $10 \%$ brine processed lactopickles. This may be explained by the fact that these products experienced the lowest degradation or fermentation, as suggested by the low level of acidity and higher accompanying $\mathrm{pH}$ values.

Many respondents commented on the relatively high salt content. The difference in acceptability recorded here and that reported by Panda et al. (2007) may be a clear pointer to the difference in the cultural regions and whether or not the consumers regularly eat foods with high levels of salt and a sour taste. The respondents used in this case had a lower appreciation of the product in this regard. This, however, provides an avenue for improving the product by adding sugar. This way, Panda and Ray (2007) were able to demonstrate higher test scores on all the attributes (texture, taste, Aroma, Flavour, and after taste) under investigation.

Sensory evaluation is a unique discipline that makes use of experimental design and statistical analysis concepts to human senses, with the aim of evaluating consumer products (Kuenzel, Zandstra, El Deredy, Blanchette, \& Thomas, 2011). The main tool for sensory analysis is often descriptive, based on a given scale (Allgeyer, Miller, \& Lee, 2010). Either the panellists are trained on the experiences of a particular attribute (Bayarri, Carbonell, Barrios, \& Costell, 2011) or they may not be specifically trained. The latter is especially used where a manufacturer is only interested in whether or not their product is acceptable to their target consumer. These subjective attributes are therefore used to discriminate and distinguish products based on aroma, flavor, texture, after taste, and sound properties (Kuenzel et al., 2011).

Sensory evaluation may also perform other functions such as quality control, tracking of quality changes in a product on storage and investigation of general consumer perception of a product. The resulting data helps rate products based on the chosen attributes. Correlation analysis, as well 
as the Principal Component Analysis (PCA), have been used to measure linear variations between sample variables and reduce a large number of variables to two or three principal components respectively (Panda et al., 2007). Sensory analysis therefore showed the panellists' scores on the basis of their acceptability and preference for the selected attributes of after taste, appearance, and flavour.

\section{Conclusions}

To conclude, this paper demonstrated that OFSP varieties are very rich in many important nutrients including crude protein, crude fat, starch dietary fibre, Ash, mineral content (Zinc and Iron), ascorbic acid and $\beta$-carotene. This confirms previous studies that OFSPs are among the most nutritious food products. It also demonstrated that the Zapallo variety recorded the highest amount of $\beta$-carotene among the three OFSPs analysed. The resulting product of the fermentation of OFSP (Zapallo) using Lactobacillus plantarum had high $\beta$-carotene retention with the average reported at $93.94 \%$ after processing. The product had a final $\mathrm{pH}$ of 3.27 and remained free of spoilage organisms after the fermentation period of 28 days. The fermented products received a favourable panellist evaluation for flavour profiling scores. The product sensory scores were (1.5-2.7) on a 5 point hedonic scale ranging from dislike slightly to like much. The product with brine levels at 4 and $6 \%$ were most preferred. These products received favourable scores both for taste and flavour and had higher levels of $\beta$ carotene. They also had the highest amount of Ascorbic acid. The resulting product was moderately liked by panellists and, since it has a high level of $\beta$-carotene, has a potential for reducing VAD on its regular consumption, especially among pregnant women and children. Of interest for further study is to determine if addition of sugar and pectinase enzymes will improve the product and thus the consumer acceptability.

\section{Acknowledgements}

The authors are grateful to the National Council for Science and Technology (NCST), Kenya for the research grant which enabled this study. We are also grateful to the Kenya Industrial Research Development Institute (KIRDI), Kenya Agricultural Research Institute KARI, and Department of Food Science Egerton University for allowing use of their laboratories, which were vital in conducting the research.

\section{References}

Abdel-Gayoum \& Abdel-Rahman. (2012). Characterization of three genotypes of sweetpotato and their suitability for jam making. 2(1), 1-9. Retrieved from http : / / azurihealth. webs. com / azurihealthproducts.htm

Adams, M. \& Nicolaides, L. (1997). Review of the sensitivity of different foodborne pathogens to fermentation. Food Control, 8(5-6), 227239. doi:10.1016/S0956-7135(97)00016-9

Allgeyer, L., Miller, M., \& Lee, S. (2010). Sensory and microbiological quality of yogurt drinks with prebiotics and probiotics. Journal of Dairy Science, 93(10), 4471-4479. doi:10.3168/jds.2009-2582

AOAC. (1984). Official methods of analysis. 14th ed.

AOAC. (2000). Official methods of analysis. vol. I. 1 thth ed.

AOAC. (2003). Official methods of analysis of the association of official's analytical chemists, 17 th ed.

AOAC. (2005). Official methods of analysis, 16th ed.

Arvanitoyannis, I. (2006). Novel food processing technologies. International Journal of Food Science and Technology, 41(4), 470-474.

Azuri Health Products. (2011). A healthy family knows. Retrieved from http://azurihealth. webs.com/azurihealthproducts.htm

Bayarri, S., Carbonell, I., Barrios, E., \& Costell, E. (2011). Impact of sensory differences on consumer acceptability of yoghurt and yoghurt-like products. International Dairy Journal, 21(2), 111-118. doi:10.1016/ j. idairyj.2010.09.002

Bengtsson, A., Narnutebi, A., Alminger, M. L., \& Svanberga, U. (2008). Effects of various traditional processing methods on the all- 
trans- $\beta$-carotene content of orange-fleshed sweet potato. Journal Food Composition and Analysis, 21 (2), 134-143. doi:10.1016/ j.jfca.2007.09.006

Burgos, G., Carpio, R., Sanchez, C., Sosa, P., Porras, E., Espi Noza, J., \& Gruneberg, W. (2009). Guide for using the rhs colour chart for selecting for high $\beta$-carotene sweet potato. ISTRC, Lima, Peru.

Carey, E. E., Hagenimana, V., K'osambo, L., Oyunga, M., Benesi, I., Smit, N., ... Low, J. (1998). Using orange-fleshed sweetpotato varieties to combat vitamin $\mathrm{A}$ deficiency and enhance market opportunities for smallholder farmers in sub-Saharan Africa. Food Security and Crop Diversification in SADC Countries: The Role of Cassava and Sweetpotato, 17-19.

Carey, E. E., Oyunga, M. A., K'osambo, L. N. E., Smit, J. M., Ocitti, C., p'Obwoya, ... Hagenimana, V. (2012). Using orange-fleshed sweet potato varieties to combat vitamin $A$ deficiency and enhance market opportunities for smallholder farmers in sub-Saharan Africa. U. Kenya Agricultural Research Institute (KARI), National Potato Research Center-Tigoni, Limuru, Kenya.

Chukwu, O., Nwadike, N., \& Nwachukwu, N. (2012). Effects of cooking and frying on antioxidants present in sweet potatoes (Ipomoea batatas). Academic Research International, 2(2), 104-109.

CIP. (2010). Facts and figures about sweet potato pdf. Retrieved from http : / / sweetpotatoknowledge . org / sweetpotato introduction / Facts \% 20and \% 20Figures \% 20about\%20Sweetpotato.pdf/view

Cummings, B. (2005). Growing sweet potato in east texas. Van Zandt County Extension Bulletin.

Degras, L. et al. (2003). Sweet potato. MacMillan. Demir, N., Acar, J., Sarığlu, K., \& Mutlu, M. (2001). The use of commercial pectinase in fruit juice industry. part 3: immobilized pectinase for mash treatment. Journal of Food Engineering, 47(4), 275-280.

FAOSTAT. (2005). Food and agricultural statistical database. Retrieved from http:// faostat.fao.org
FAOSTAT. (2011). Food and agricultural statistical database. Retrieved from http:// faostat.fao.org

FAO/WHO. (1988). Requirements of Vitamin $A$, Iron, Folate and Vitamin B Report of a Joint FAO/WHO Expert Consultation. FAO, Rome.

Farinu, A. \& Baik, O.-D. (2007). Thermal properties of sweet potato with its moisture content and temperature. International Journal of Food Properties, 10(4), 703-719. doi:10.1080/10942910601137482

Gardner, N., Savard, T., Obermeier, P., Caldwell, G., \& Champagne, C. (2001). Selection and characterization of mixed starter cultures for lactic acid fermentation of carrot, cabbage, beet and onion vegetable mixtures. International Journal of Food Microbiology, 64(3), 261-275. doi:10.1016/S0168 1605(00)00461-X

Giraud, E., Brauman, A., Keleke, S., Lelong, B., \& Raimbault, M. (1991). Isolation and physiological study of an amylolytic strain of lactobacillus-plantarum. Applied Microbiology and Biotechnology, 36(3), 379-383.

Gul, S. \& Safdar, M. (2000). Proximate composition and mineral analysis of cinnamon. Pakistan Journal of Nutrition, 8(9), 14561460.

Hagenimana, V., Carey, E. E., Gichuki, S. T., Oyunga, M. A., \& Imungi, J. K. (1998). Carotenoid contents infresh, dried and processed sweetpotato products. Ecology of Food and Nutrition, 37(5), 455-473.

Hagenimana, V. \& Low, J. (2000). Potential of orange-fleshed sweet potatoes for raising vitamin A intake in Africa. Food and $\mathrm{Nu}$ trition Bulletin, 21 (4), 414-418.

Haralampu, S. \& Karel, M. (1983). Kineticmodels for moisture dependence of ascorbic-acid and $\beta$-carotene degradation in dehydrated sweet-potato. Journal Of Food Science, 48(6), 1872-1873. doi:10.1111/j.1365-2621.1983.tb05106.x

Hart, D. \& Scott, K. (1995). Development and evaluation of an hplc method for the analysis of carotenoids in foods, and the measurement of the carotenoid content of vegetables and fruits commonly consumed in 
the uk. Food Chemistry, 54(1), 101-111. doi:10.1016/0308-8146(95)92669-B

Huang, A., Tanudjaja, L., \& Lum, D. (1999). Content of alpha- $\beta$ - and dietary fibre in 18 sweet potato varieties grown in hawaii. Journal of Food Composition and Analysis, 12(2), 147-15.

Hussain, I., Zeb, A., Shakir, I., \& Shah, A. (2008). Combine effect of potassium sorbate and sodium benzoate on individual and blended juices of apricot and apple fruits grown in azad jammu and kashmir. Pak. J. Nutr. 7(1), 181-185.

Imungi, J. \& Wabule, M. (1990). Some Chemical Characteristics and availability of Vitamin $\mathrm{A}$ and Vitamin $\mathrm{C}$ from Kenyan varieties of Papayas (Carica papaya L.) Ecology of Food and Nutrition, 24(2), 115-120.

Jackobsen, J. (2011). Improve post-harvest management and marketing. sweet potato knowledge portal. Retrieved from http : / / sweetpotatoknowledge . org / adding value/port-harvest-handling/Improving \% 20post \% 20harvest \% 20management \% 20and \% 20marketing\%20R8273_FTR.pdf/ view

Jaetzold, R. \& Schmidt, H. (2007). Farm management handbook of kenya. Vols.II $B$ Central Kenya (Rift Valley and Central Provinces). Ministry of Agriculture in cooperation with GAT of GTZ, Nairobi.

Kaguongo, W., Ortmann, G., Wale, E., Darroch, M., \& Low, J. (2012). Factors influencing adoption and intensity of adoption of orange flesh sweet potato varieties: evidence from an extension intervention in nyanza and western provinces, kenya. African Journal of Agricultural Research, 7(3), 493-503.

Kapinga, R. E., Andrade, M., Lemaga, B., Amanada, G., Crissman, C., \& Wwanga, R. (2005). Role of orange fleshed sweet potatoes in disaster mitigation: experiences from east and southern africa. Africa crop science conference proceedings, 7, 3211329.

Kapinga, R. E. \& Carey, E. E. (2003). Present status of sweet potato breeding for eastern and southern africa (U. o. G. London: Natural Resource Institute, Ed.). In:
Rees, D.O.Q. and Kapinga, R. (eds.) Sweet potato post-harvest assessment: Experience from East Africa.

Kaur, C. \& Kapoor, H. (2001). Antioxidants in fruits and vegetables - the millennium's health. International Journal of Food Science and Technology, 36(7), 703725. doi:10.1046/j.1365-2621.2001.00513.x

Kilcast, D. \& Subramaniam, P. (2000). The stability and shelf-life of food. Woodhead Food Series. Cambridge: Woodhead Publishing Limited. Retrieved from http://books . google.pt/books?id=UxHdNb2aaZcC

Kim, H., Min, J., Lee, J., \& Ji, G. (2000). Growth of lactic acid bacteria and bifidobacteria in natural media using vegetables, seaweeds, grains and potatoes. Food Sci. Biotechnol, 9, 322-324.

Konczak, I., Okuno, S., Yoshimoto, M., \& Konczak, I. (2004). Caffeoylquinic acids generated in vitro in a high-anthocyaninaccumulating sweet potato cell line. Journal of Biomedicine and Biotechnology, (5), 287-292.

K'osambo, L., Carey, E. E., Misra, A., Wilkes, J., \& Hagenimana, V. (1998). Influence of Age, Farming Site, and Boiling on ProVitamin A Content in Sweet Potato (Ipomoea batatas (L.) Lam.) Storage Roots. Journal of Food Composition and Analysis, 11 (4), 305-321. doi:10.1006/jfca.1998.0591

Kuenzel, J., Zandstra, E. H., El Deredy, W., Blanchette, I., \& Thomas, A. (2011). Expecting yoghurt drinks to taste sweet or pleasant increases liking. Appetite, 56(1), 122-127. doi:10.1016/j.appet.2010.12.009

Kumar, P. \& Mishra, H. (2004). Mango soy fortified set yoghurt: effect of stabilizer addition on physicochemical, sensory and textural properties. Food Chemistry, 87(4), 501-507. doi:10.1016/j.foodchem.2003.12. 022

Mahadevan, A. \& Sridhar, R. (1993). Sivakami publication, madras, india. Methods in Physiological Plant Pathology, $5^{\text {th }}$ Ed.

Molin, G. (2008). Lactobacillus plantarum: the role in foods and in human health $(\mathrm{H}$. of Fermented Functional Foods. Second \& revised edition. New York: CRC Press, Eds.). In Farnworth, Edward (Eds.) 
Montet, D., Loiseau, G., \& Zakhia-Rozis, N. (2006). Microbial technology of fermented vegetables (R. In Ray \& O. ( Ward, Eds.). Microbial Biotechnology in Horticulture, Vol 1 (309-343) Enfield: Science Publishers Inc.

Muchoki, C., Imungi, J., \& Lamuka, P. (2007). Changes in $\beta$-carotene, ascorbic acid and sensory properties in fermented, solar-dried and stored cowpea leaf vegetables. African Journal of Food Agriculture, Nutrition and Development, 7(3), 1-20.

Mwanri, A., Kogi-Makau, W., \& Laswai, H. (2011). Nutrients and antinutrients composition of raw, cooked and sun-dried sweet potato leaves. African Journal of Food Agriculture, Nutrition and Development, $11(5), 1-6$.

Ndolo, P., Nungo, R., R.E., K., \& Agili, S. (2007). Development and promotion of orangefleshed sweet potato varieties in western kenya: in the proceedings of the 13 th istrc symposium. paper presented at $13 \mathrm{th}$ istrc symposium ,held at arusha, tanzania, 10-14 november, 2003. (pp. 689-695). Tanzania: Maruku Agricultural Research Institute.

Nshimiyimana, E. (2012). Application of windhexe dehydration technology for producing $\beta$-carotene rich flours from sweet potatoes (Master's thesis, Presented at North Carolina State University. Raleigh, North Carolina).

Panda, S. H., Parmanick, M., \& Ray, R. C. (2007). Lactic acid fermentation of sweet potato (Ipomoea batatas 1.) into pickles. Journal of Food Processing and Preservation, 31(1), 83-101. doi:10.1111/j.17454549.2007.00110.x

Panda, S. H. \& Ray, R. C. (2007). Lactic acid fermentation of $\beta$-carotene rich sweet potato (Ipomoea batatas 1.) into lacto-juice. Plant Foods for Human Nutrition, 62(2), 65-70. doi:10.1007/s11130-007-0043-y

Rajendran, R. \& Ohta, Y. (1998). Binding of heterocyclic amines by lactic acid bacteria from miso, a fermented japanese food. Canadian Journal of Microbiology, 44(2), 109-115. doi:10.1139/cjm-44-2-109
Ranganna, S. (2001). New dehli: tata mcgraw hill. co. ltd. Proximate analysis, colour measurement and sensory Evaluation.

Ray, R. C. \& Ward, O. P. (2006). Post-harvest microbial biotechnology of tropical root and tuber crops (I. R. Ray \& O. ( Ward, Eds.). Microbial Biotechnology in Horticulture, Enfield: Science Publishers Inc.

Rodriguez-Amaya, D., Kimura, M., Institute, I. F. P. R., \& de Agricultura Tropical, C. I. (2004). Harvestplus handbook for carotenoid analysis. HarvestPlus Technical Monographs. International Food Policy Research Institute (IFPRI). Retrieved from http : / / books . google $\cdot$ pt / books ? id = $\lg 4 \mathrm{FtwAACAAJ}$

Suda, I., Oki, T., Masuda, M., Kobayashi, Y., M.and Nishiba, \& Furuta, S. (2003). Physiological functionality of purple-fleshed sweet potatoes containing anthocyanins and their utilization in foods. Jarq-Japan Agricultural Research Quarterly, 37(3), 167-173.

Takahata, Y., Noda, T., \& Nagata, T. (1993). Hplc determination of $\beta$-carotene content of sweet-potato cultivars and its relationship with color values. Japanese Journal of Breeding, 43(3), 421-427.

Tewe, O. (1994). Sweet potato utilization in poultry diets. Acta Horticulturae, 380, 426-435.

Tomlins, K., Owori, C., Bechoff, A., Menya, G., \& Westby, A. (2012). Relationship among the carotenoid content, dry matter content and sensory attributes of sweet potato. Food Chemistry, 131(1), 14-21. doi:10 . 1016/j.foodchem.2011.07.072

Troung, R., V.D. andThompson, McFeeters, R., \& Lanier, M. (2004). Phenolic compounds and antioxidant activity of commercial sweet potato cultivars. In IFT Annual Meeting Book of Abstracts. Paper presented at IFT Annual Meeting, held at New Orleans, U.S.A, 22-26 June 2004 (Abstract number 49F-27). Chicago: Inst. of Food Technologists.

Trumbo, P., Yates, A., Schlicker, S., \& Poos, M. (2001). Dietary reference intakes for vitamin A, vitamin $\mathrm{K}$, arsenic, boron, chromium, copper, iodine, iron, manganese, molybdenum, nickel, silicon, vana- 
dium, and zinc. Journal of the American Dietetic Association, 101(3), 294-301. doi:10.1016/S0002-8223(01)00078-5

Ukpabi, U., Ekeledo, E., \& Ezigbo, V. (2012). Potential use of roots of orange-fleshed sweet potato genotypes in the production of $\beta$ carotene rich chips in nigeria. African Journal of Food Science, 6(2), 29-33.

US IOM. (2001). Dietary reference intakes for vitamin A, vitamin $\mathrm{K}$, arsenic, boron, chromium, copper, iodine, iron, manganese, molybdenum, nickel, silicon, vanadium, and zinc. Washington: Institute of Medicine of the National Academics.

van Jaarsveld, P., Faber, M., Tanumihardjo, S., Nestel, P. ., Lombard, C., \& Benade, A. (2005). $\beta$-Carotene-rich orangefleshed sweet potato improves the vitamin A status of primary school children assessed with the modified-relative-doseresponse test. American Journal of Clinical Nutrition, 81(5), 1080-1087.

van Jaarsveld, P., Marais, D., Harmse, E., Nestel, P., \& Rodriguez-Amaya, D. (2006). Retention of $\beta$-carotene in boiled, mashed orange-fleshed sweet potato. Journal of Food Composition and Analysis, 19(4), 321-329. doi:10.1016/j.jfca.2004.10.007

Vimala, B., Sreekanth, A., Binua, H., \& Wolfgang, G. (2011). Variability in 42 orangefleshed sweet potato hybrids for tuber yield and carotene \& dry matter content. Geneconserve, 40, 190-200.

WFP. (2002). Food quality control. Food Nutritional Quality : Micronutrients : Recommended Nutrient Intakes. Retrieved from http : / / foodquality. wfp. org / Portals / 0 / RNI_minerals_WHO_2002.swf

Xin, W., Chengjun, S., Liuhua, Y., Guo, Z., Zuyang, L., \& Yumin, L. (2008). $\beta$-carotene content in sweet potato varieties from china and the effect of preparation on $\beta$-carotene retention in the yanshu no. 5. Innovative Food Science and Emerging Technologies, 9(4), 581-586.

Yamakawa, O. \& Yoshimoto, M. (2001). Sweetpotato as food material with physiological functions. In I international conference on sweetpotato. food and health for the future 583 (pp. 179-185). 